
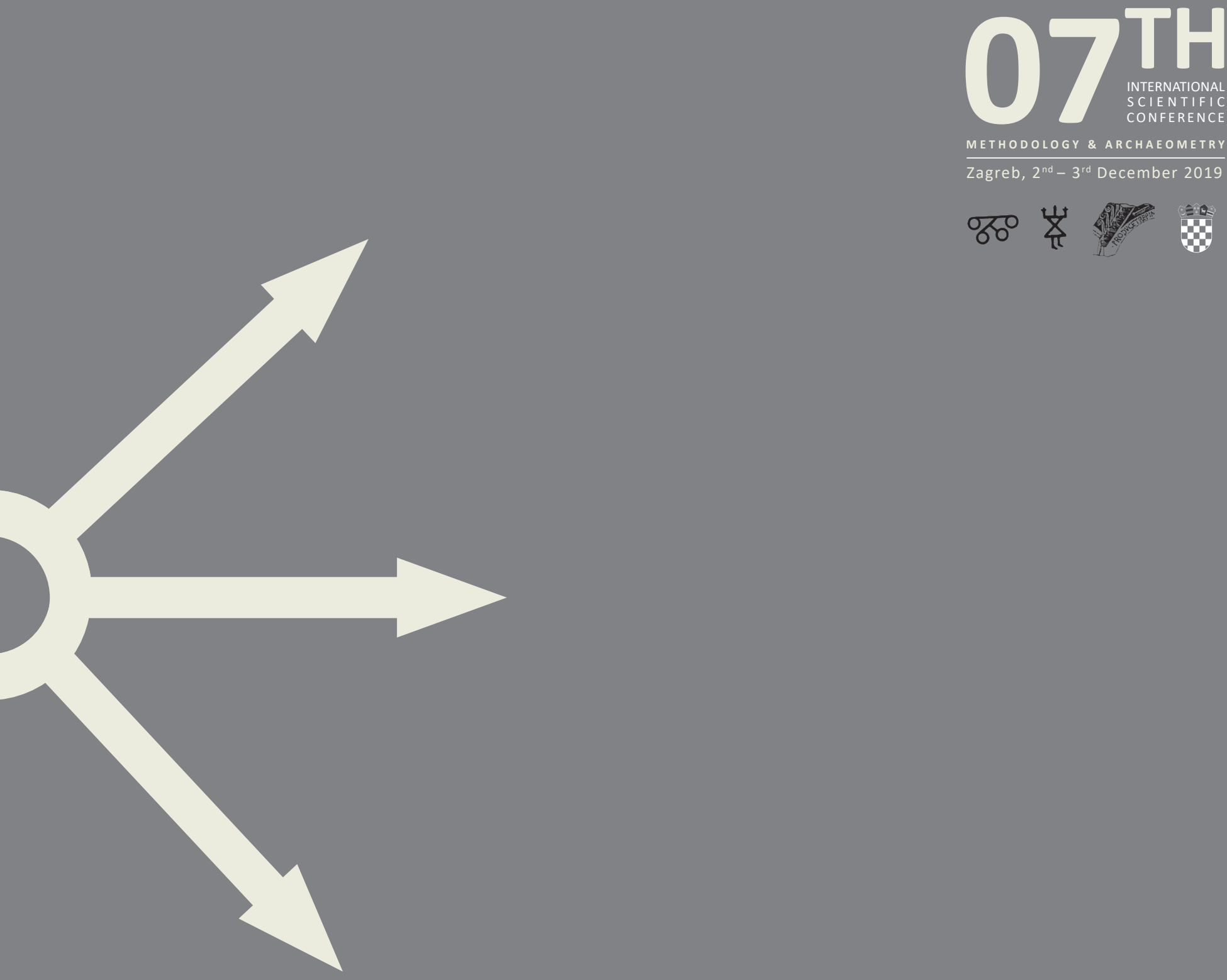
\%ㅇㅇ 岗

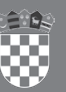
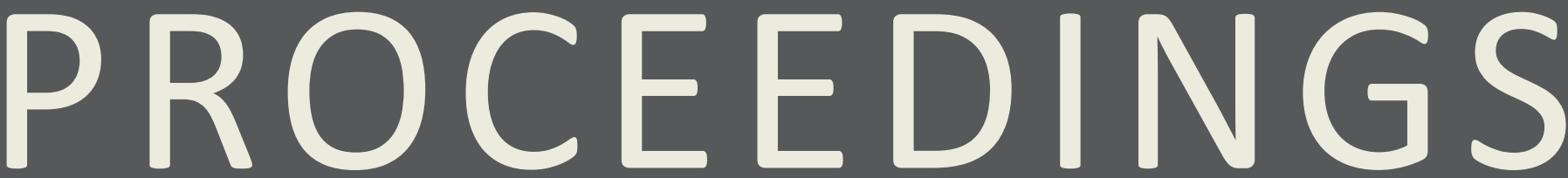

FROM THE $7^{\text {TH }}$ SCIENTIFIC CONFERENCE METHODOLOGY AND ARCHAEOMETRY 


\section{IMPRESSUM}

PUBLISHER

Faculty of Humanities and Social Sciences, University of Zagreb

FOR THE PUBLISHER

Miljenko Šimpraga

EDITOR

Ina Miloglav

Faculty of Humanities and Social Sciences, University of Zagreb

EDITORIAL BOARD

Predrag Novaković

Faculty of Arts, University of Ljubljana, Slovenia

Dimitrij Mlekuž

Faculty of Arts, University of Ljubljana

\& Centre for preventive archaeology, Ljubljana, Slovenia

Michela Spataro

The British Museum, London, United Kingdom

Duska Urem-Kotsou

Democritus University of Thrace, Komotini, Greece

Jasna Vuković

Faculty of Philosophy, University of Belgrade, Serbia

Rajna Šošić Klindžić

Faculty of Humanities and Social Sciences, University of Zagreb, Croatia

Jacqueline Balen

Archaeological Museum in Zagreb, Croatia

DESIGN \& DTP

Srećko Škrinjarić

All papers were reviewed in the peer review process in which the identity of both reviewers and authors, as well as their institutions, are respectfully concealed from both parties.

DOI

https://doi.org/10.17234/METARH.2020

ISSN 2718-2916

Faculty of Humanities and Social Sciences of the University of Zagreb

URL

https://openbooks.ffzg.unizg.hr/index.php/FFpress/catalog/series/MetArh http://www.ffzg.unizg.hr/metarh/

Publishing of this e-book is supported by

Ministry of Science and Education of the Republic of Croatia any medium or format, as long as they give appropriate credit, provide a link to the license, and indicate if changes were made. The content of this publication may not be used for commercial purposes. If the publication is remixed, transformed, or built 

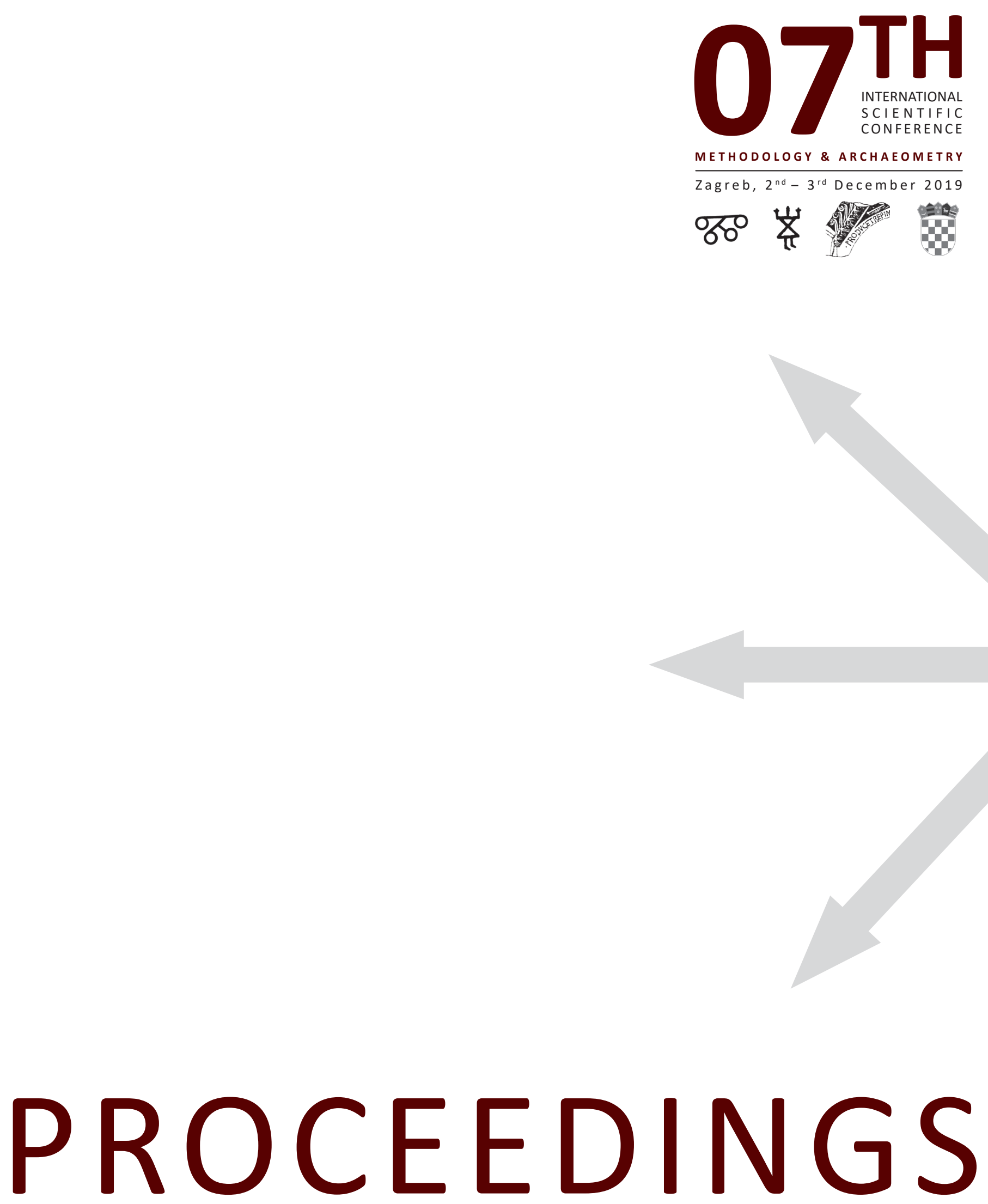

FROM THE $7^{\text {TH }}$ SCIENTIFIC CONFERENCE METHODOLOGY AND ARCHAEOMETRY 


\section{Content}

Ina Miloglav

Preface

Tamara Leskovar

09 Laboratory-based research on the changes caused to the in situ preserved archaeological remains by the heavy equipment compaction

Cornelius Meyer, Saša Kovačević, Daria Ložniak Dizdar, Mario Gavranović, Rajna Šošić-Klindžić, Tomislav Hršak, Marko Dizdar, Hrvoje Vulić, Boris Kratofil

Patterns everywhere: Geophysical prospection strategies at archaeological sites in Northern and Eastern Croatia

Domagoj Tončinić, Vinka Matijević, Miroslav Vuković

Image-based modeling approach in documenting Early Christian memorial chapel in Velić, Croatia

Esmeralda Agolli

A discussion on the theoretical and methodological ramifications of classification and typology of archaeological material: a Perspective from the Late Prehistoric Pottery (Albania)

Katarina Šprem

All aboard! Quarries and transport in Roman Istria 


\title{
A discussion on the theoretical and methodological ramifications of classification and typology of archaeological material: a Perspective from the Late Prehistoric Pottery (Albania)
}

Esmeralda Agolli

https://doi.org/10.17234/METARH.2020.05

\author{
Esmeralda Agolli \\ University of Tirana, \\ Department of Archaeology and Culture Heritage \\ Faculty of History and Philology \\ Rruga e Elbasanit \\ Tirana, Albania \\ esmeralda.agolli@unitir.edu.al
}

The paper deals with the theoretical and methodological underpinnings of classification in Albanian studies of late prehistory. By focusing on the case of pottery analysis, I discuss to what extent research in the classification and typology of archaeological data contributes to interpretations within potential patterns of materials. In so doing I follow a twofold perspective. First, I discuss some notable scholarly contributions which for almost 10 decades have elaborated extensively on this matter. It must be stressed that in Albania and more broadly in southeastern Europe such agendas yet remain peripheral and not fully explored. Second, with a specific focus on Albania, I deal with the ramifications of a conceptual synthesis in the classification of pottery material and to what extent reconstructing the chaine opératoire from the attributes of the end-product are beneficial in answering an array of scientific queries. The application of the conceptual approach shifts the analysis of late prehistoric pottery from a simple scheme of classification which at most serves as a data organizational tool, to a cohesive framework that intends to measure and evaluate the properties of pottery based on a specific research query. A classification scheme was created for every site and time period. Then, either the vessels grouped in the 'shared concepts' or vessels containing particular attributes categorized as 'individual concepts' were compared among sites in order to measure the quantitative representation of the network's models or potential connections in regional and intra-regional scale. The benefits of this scheme in pottery classification and to what extent potential patterns with weak quantitative profile impact comprehensive analysis to understand regional and intra-regional networks and beyond are some of the questions I address in the last section.

Keywords: classification, typology, type-variety system, intuitive decisions, shared system of concepts.

\section{An overview on theoretical and methodological approaches in the classification of artefacts}

I $\mathrm{n}$ this section, I take a wider view on the theoretical and methodological approaches that shaped discussion and research in classification and typology. For a variety of reasons, this discussion has been not at all considered as a question of potential interest in the studies of prehistoric material in Albania and beyond.
The inextricable connection between types and varieties or subtypes with their pertinent cultural groups comprised a pivotal argument which from the 1940s to 1970s led to crucial works in prehistory (Krieger 1944; Ford 1954; Rouse 1960; 1972). In 1944, Alex Krieger published an emblematic paper that marked an important 
step in the way the classification of artefacts was to be conceptualized. In particular, he treated the 'what's' and 'how's' that define the types and subtypes in archaeological data. Therefore, the type came considered as an indispensable element to define the characteristics of a cultural unit and its potential relationships, and also served as an organizational tool upon which further examinations were carried out. Subtype, on the other hand, comprised an integral division within the type (Krieger 1944: 271-288). Krieger did offer an integrated synthesis with a strong emphasis on the systemic level, but his theoretical premise type-subtype inherited three main limitations. First, it perceived the attributes of the data only and exclusively as a derivate of a pertinent cultural group. Second, it reduced highly the possibility to consider the degree of variability, or understand to what extent the choices of the artisan and its expertise give particular properties to the data. Third, Krieger perceived the change over time as a unified process and lacks to pay any attention to the immediate circumstances and conditions that a particular context may yield.

Rouse $(1960 ; 1972)$ argued for a classification strategy that viewed any kind of data under the cultural perspective. Indeed, he recognized that intuitive decisions of the scholar interfere significantly to the objectivity of interpretations and of course to any potential result. However, the quantitative applications to groups and patterns could remedy any subjective choice that visual classification yielded. Rouse took a broader focus on cultural remains and produced a three-pier system of classification comprised of worked and unworked equipments or artefacts. This group was based on the attributes of manufacture and use, for example, houses, axes, and vessels. From the qualitative profile, the attributes of the artefact were classified into aesthetic and functional. In a similar vein with Krieger, he used roughly similar perceptions to describe the classes and types within a category of data. A class defined a cluster of attributes classified on the basis of morphological, descriptive, phonetic, natural, or intrinsic properties. On the other hand, the types comprised 'patterns' of attributes encountered in a set of features that became the subject of research. A further attempt following the classification of the cultural remains into taxa and types regard their hierarchical organization into a larger scheme, a process which is alternatively known as taxonomic classification which organizes systematically several classes (Rouse 1972: 50-53). Rouse attempted to confine a universal order of classification that was based on the process of data collection, and its organization and interpretation. In terms of conceptualization and application, Rouse's work did not deviate considerably from that of Krieger's. Again, the equalization among the artefacts, culture, and people constrains the discussion into a problematic scheme in which any variability resulted from individual choices: other issues such as occasional expressions, or the background and expertise of the artisan, did not gain attention at all.

The equalization between culture and types or classes was mostly applied in the classification of pottery. Moreover, pottery was used as a crucial group of data for developing a classification approach coined as the 'type-variety system' (Colton and Hargrave 1937; Colton 1952; Ford 1954; Wheat et.al. 1958; Gifford 1960). The approach introduced two basic aspects. First, it promoted at best a cohesive connection between culture and types. Second, it brought a dynamic perspective that integrated the theoretical underpinnings with the methodological applications by using the properties of pottery data.

In a similar vein with Rouse, Gifford (1960: 342-343) defined the so-called pottery type as a group of attributes that bear cultural salience. Moreover, through a pottery type, one can perceive openly the shared concepts of a culture and also the degree of interactions within it. The artisan embodies his production attributes and features of a pertinent cultural environment into his craft which Gifford refers to as a shared system of concepts. Thus, a type must represent a group of individual choices that reflect other dimensions including the artisan's status within the social environment, imitations, and other kinds of influences. The variety on the other hand, bears variations, strictly associated with the individual choices but relational to the type (Gifford 1960: 345). Gifford elaborated on this approach which had earlier been introduced by a group of authors, including him (Wheat et. al. 1958).

It must be stressed that during the 1960s the type-variety system was rather popular but remained within vague boundaries that evoked essential problems in the classification of pottery. Most of its critiques focused on the perceptions of type and varieties and their frozen equalization with culture. Much later, Dwight Read (2007:94) would argue that simply by assigning cultural salience to a type one cannot easily distinguish nor fully analyze the dimensions of a repertoire. According to him: not all the possible quantitative dimensions of an artefact are culturally salient and even for a culturally salient dimension, there will be variation arising from the fact that 
the value for a dimension need not to be mapped in an identical manner onto each artefact (Read 2007: 199). Among other remarks, Read (2007: 56-57) noticed the problematic gap between the assignment of types and varieties and the role that the intuitive choices of the scholar played on such definition. Against this backdrop, he introduced an approach that combined inductive and deductive principles and elaborated a classification system that relies on a triple conceptual association among the cultural unit, the actions of artisan, and the properties of artefacts. Read succeeded to produce a methodological framework that was narrowly defined under the premises of 'thinking' and 'action' and the extent they are confined by the means of culture, exchange, individual expressions, imitations, and inheritance. Type and typology yet remained a valid avenue of his approach, however, as Read (2007: 199-240) argued, such a scheme was to be pursued through comprehensive analysis and selection of qualitative attributes through the evaluation of every ideational and physical action that produces an artefact from the extraction of the raw material to the formation of the end-product. The quantitative dimension became an irreplaceable parameter for measuring the significant groups and patterns of a repertoire. Reads remedied rather significantly the discrepancies of the type-variety system by avoiding the intuitive choices of the scholar and dissolving the imperative connection between culture and types.

Much earlier, Adams and Adams (1991) had provided yet another beneficial advancement especially for the methodological implications of classification and typology. They recognized the complexity of the matter and saw rather skeptically the potential for a cohesive classification scheme that could be universally applied to the archaeological data. The immense variety and nature of the data was a crucial impediment that greatly complicated this endeavor. Instead, Adams and Adams applied a purpose-oriented approach to a particular set of data, with the case of Medieval Nubian Pottery. They distinguished three kinds of purposes together with their corresponding categories including: basic (descriptive, comparative, analytical, intrinsic, interpretative, and historical), instrumental (ancillary, incidental), and multiple (Adams and Adams 1991: 158-168). It's to be expected that this new conceptual order did not fully avoid intuitive decisions. However, the approach offered an effective conceptual and methodological framework that facilitated further analysis of the data and certainly opened a venue to address more specific scientific queries.
In addition, I dealt in this section with the theoretical and methodological approaches that in the last decades contributed a great deal to the discussion of classification in the archaeological artefacts. It remains however valid, that such a vivid debate on various matters yet lacks to offer a cohesive approach that can be cogently applied to any kind of archaeological data. Despite the attention that each of the above approaches gives to the methodological framework, especially with pottery, they rather perceive it in a perfect state of preservation and give insufficient attention to the fragmentary state in which this kind of data is collected in the field and how the low degree of preservation could impact further analysis of the qualitative or quantitative profile. This is a limitation that none of the above authors considers or addresses as a crucial impediment in the classification process.

\section{The classification of artefacts in Albanian studies: an overview on the current state of research}

Pottery studies of late prehistory in Albania, have been carried out within the framework of the culture-historical approach. Due to the simplistic implications that such approach evokes, classification and typology was generally overlooked and not treated as a question of potential importance. Any interpretation or discussion so far continuously focuses on the qualitative properties $^{1}$ of the archaeological artefacts, mainly pottery and metal finds. I have discussed elsewhere the dynamics of research geared especially towards the qualitative and quantitative profile of repertoires that massive campaigns of fieldwork have produced in Albania (Agolli 2019: 25-42).

However, even with the qualitative profile, classification and typology in the most simplistic terms find their utilization only with the organization and order of the archaeological data. With pottery, for instance, complete vessels were organized according to schemes of classification that was ordered on the basis of fabric (mostly designated by macroscopic examinations) and vessel form organized according to the interrelated type-variety system. For each designated group, accounts were mostly provided regarding regional and intraregional comparanda with an exclusive focus on cultural affinities. The parameters and attributes that designate the types or varieties are hardly mentioned, making this

\footnotetext{
${ }^{1}$ The qualitative profile it refers to diagnostic traits of pottery data created by the artisan that shape measurable features.
} 


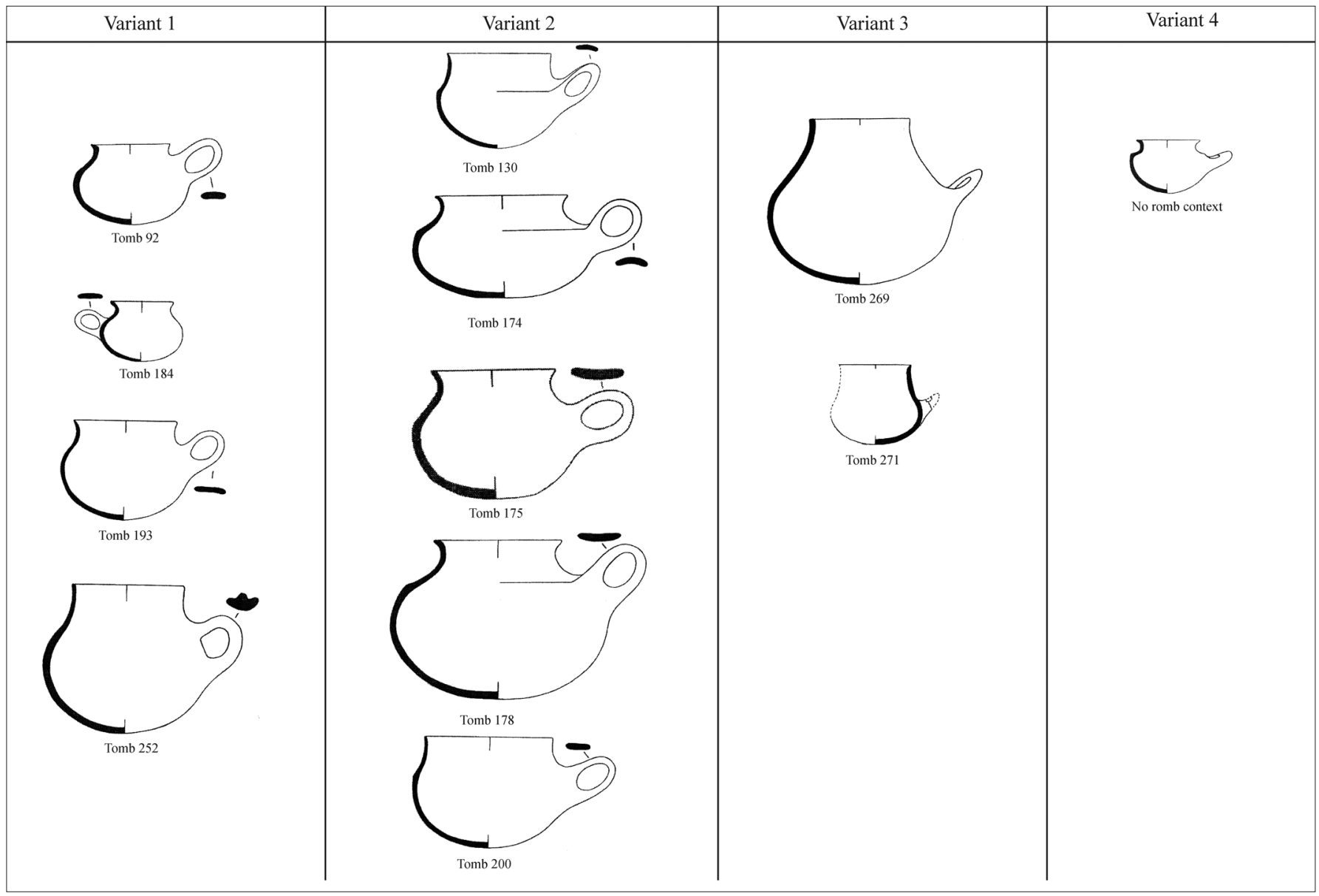

Figure 1. Type-Variety applied in the classification of one-handled vessels - the case of Rehovë Tumulus (Aliu 2012).

process highly subjective. In other words, it seems likely that such undertaking relies heavily on the intuitive decisions of the archaeologist. For instance, in the case of Rehovë tumulus, (Aliu 2012: 167-187), the crucial attribute that designates the types in the handmade pottery assemblage is the number of handles; other features like, the form of neck or body and handle emplacement rather vaguely define the varieties (see Fig. 1) (Aliu 2012: 168-169). Aliu does not provide much background on the 'how's' and 'why's' of such a strategy in the classification of material. Furthermore, this strictly taxonomic approach is noticed in papers that focus on much conclusive matters including cultural background and continuity, or even ethnogenesis (Aliu 1984; 1994; 1995; 1996; 2002; Andrea 1985; 2009; Bodinaku 1989; 1990; 2001; Hoti 1981; Jubani 1969; 1982; 1983; Korkuti 1969; 1971; 1981; Korkuti - Bunguri 1996; Prendi 1956; 1957; $1959 ; 1966 ; 1974 ; 1977)$. At any case, qualitative properties of pottery mainly describe salient parameters like decoration, vessel form, or handle form and location are compared in synchronic or diachronic order attempting to derive connections and networks with neighboring cultures. Some crucial conclusions of Albanian prehistory have relied on this kind of reasoning.

Recently, a few studies that focus on quantitative analysis and attempt to avoid pre-defined and intuitive assumptions have been discussed (Aliu and Bejko 2009; Agolli 2009; 2014). Among others, an interesting example is associated with the classification and typology of the fibulae found in the prehistoric cemeteries of the Kolonje plateau (Aliu and Bejko 2009: 59-103). As a case study to demonstrate how subjective qualitative analysis can be, Aliu and Bejko have agreed to apply two contradictive methods in the classification of the fibulae repertoire. The first, known as the traditional method, is based on a type-variety system with types and varieties assigned arbitrarily such as XYZ. Among other narratives, mostly touching upon which cultures can be attested based on the preponderance of these types and varieties outside Kolonjë plateau, with the case of the spectacle fibulae especially, the form of the 'eight' (single or double) between the discs is considered as a 
salient/definitive attribute. The second, named as the 'independent' method implies the statistical inference. This method does not disqualify the principles of the traditional method but avoids to claim any pre-defined preference among them. ${ }^{2}$ The seriation and correspondence analysis identify as a significant typological feature the section of the wire and no single or double 'eight' figure between the discs. For both authors, however, this distinction may also bear chronological significance (Aliu and Bejko 2009: 85, 94).

Bejko and Aliu attempted to integrate 'peacefully' this contradiction between these conceptual and methodological approaches, which must be said could hardly be combined. This is at best seen from the controversial results that each of these methods yielded. Despite this outcome, however, the implication of the statistical inference with the classification of the archaeological data must be considered as a successful attempt to challenge the simplistic typological schemes that rely on visual evaluations of physical properties.

Although various recent studies do not address the theoretical implications of classification as a central query they do give careful attention to the macroscopic and microscopic observations of the pottery properties and, while focusing on the compilation of catalogues, offer to the greatest extent a coherent and detailed emphasis on the physical and aesthetic properties. Above all, they avoid any intuitive decision that gives prevalence to the qualitative properties of the data (Gori 2015; Krapf 2014; Pevnick and Agolli 2014). This amount of research allows for subsequent research attempts to further address innovative theoretical and methodological agendas.

In addition, the theoretical and methodological underpinnings of classification and typology in late prehistoric archaeological pottery in Albania yet remains at a seminal stage. Despite some sporadic innovative attempts, the type-variety system of classification yet is simply used as a tool that helps to bring order to the data at which the intuitive decisions of the archaeologist play a key role. The main purpose here is been the designation of groups with similar properties through a strategy that perceived 'pots = people' and searched mainly for cultural affinities in both inter and intra-regional scale.

\footnotetext{
${ }^{2}$ From a personal communication, each author applied to the repertoire a different methodology. Aliu chose to apply the traditional method and Bejko reprocessed the data by using the seriation and correspondence analysis.
}

The benefits of the conceptual classification approach in the analysis of late prehistoric pottery in Albania

In this section, I focus on the implications of the conceptual classification framework. I applied this approach in my dissertation research on the late prehistoric pottery of Albania (Agolli 2014). Given the quantitative and qualitative profile of pottery repertoires encountered mostly in tumuli burials, the application of a classification framework that took a comprehensive overview on the properties of the pottery data was of great relevance. ${ }^{3}$ This became even more valid if into consideration was taken the fact that largely these repertoires were comprised of complete or nearly complete vessels, meaning they possess the potential to accommodate a full synopsis the evaluation of properties adapted from the aforementioned approaches of Read and Adams and Adams.

The research was oriented towards two specific queries; to evaluate the regional networks among the late prehistoric communities (Albania) in a synchronic and diachronic perspective as well as to evaluate the innovation of pottery production over time at the site level. The measurement of similarities and differences among pottery repertoires at various sites comprised the backbone of this analysis (Agolli 2014: 40-46). Each repertoire was classified through a scheme that attempted to avoid when possible intuitive decisions and employed a conceptual framework that focused on the ideational profile of the material, ${ }^{4}$ an approach elaborated in detail by Dwight Read (Read 2007). The principal parameter of classification took into investigation attributes that could be obtained from the properties of the end-product. I attempted to analyze the ideational profile by taking a detailed synopsis at three primary parameters: fabric, vessel formation, and decoration. Fabric and surface treatment are treated very briefly in Albanian publications and systematic evidence for both parameters was not collected systematically. Detailed observations of the qualitative attributes of pottery created a comprehensive understanding of attributes that occurred most commonly and were classified as - shared concepts. On the other hand, attributes that marked rare occurrence were classified as - individual concepts. ${ }^{5}$ Each pottery

\footnotetext{
${ }^{3}$ The research conducted analysis in the pottery assemblages recovered in 35 tumuli, 1 shaft cemetery and 10 settlements. In total, an amount of 1476 complete vessels was subject of analysis.

${ }^{4}$ The ideational profile defines the understanding of the steps an artisan takes during the process of production.
} 
repertoire was situated within a key diagram that counted on identifying choices undertaken in the making of pottery. The scheme of the key diagram has not yet been applied to the pottery studies. In mortuary analysis however, this technique has offered tangible results regarding the distribution of data properties (Brown 1971; Morris 1987; Papadopoulos 2005). Brown described the key diagram as a mechanism to express the partitioning of attribute space by a series of variables coded for an independently measured dimension (Brown 1971: 90). I proposed that this method held a great potential for pottery analysis, especially for the separation of choices implied in the object.

The choices (concepts) made on vessels were divided into five aspects defined either as absolute or relative distinctions. Thus, those decisions that can be clearly distinguished were assigned as absolute distinctions, such as handles, number of handles, and their location, the form of the base, and techniques of decoration. The categories of the form of neck and vessel size were defined as relative distinctions on account of their fluid variability. In the majority of cases, the form of the neck remained an attribute with no salient distinction and thus remained a relative attribute. For instance, in every chronological phase, depending on the general properties of the repertoire, the form of the neck is roughly defined as short, cylindrical, conical, or elongated. Vessel size has been classified as small-medium or large. Such distinctions were based on macroscopic observation in which both classes may be clearly separated. This attribute was also assigned as a relative distinction. Any assumption regarding vessel function was not considered, since the repertoire or archaeological context offered no conclusive determination. Each of the chronological phases of the site was assigned its own group of concepts, according to the degree of variability.

Given that this paper deals with the theoretical and methodological underpinnings, I turn now to the potential outputs of the conceptual framework. Despite the quantitative profile, once vessels were distributed according to the pre-defined attributes in the key diagram, at least in the shared system of concepts, the most representative and homogeneous groups were those comprised of five to six vessels at maximum. For instance,

\footnotetext{
${ }^{5}$ Both concepts were earlier introduced by Gifford 1960. In this research none of them bears a cultural salience, they only represent choices of the artisan physically implied in the data. For a definition of each concept see: Agolli 2014: 46-47.
}

in the case of Prodan tumulus, the shared system of concepts in the fourth division dropped to four, three or even two vessels. Not to mention that ten vessels within this repertoire embodied individual concepts and could not be situated in any group at all (see Fig. 2). The tumulus of Prodan served as an example but such quantitative profile did not offer any potential for further analysis that could involve the statistical inference at other sites as well.

However, the conceptual classification based on the qualitative attributes produced a strong background to conduct regional and intra-regional comparisons as well as measure how innovative choices among sites could be measured in the diachronic order. Several questions related to any meaningful distribution of vessel forms and decorative techniques, or any pattern which at one site could be more significant than in another could be assessed only through the weak quantitative profile that groups in the key diagrams offered. Nevertheless, comparisons among site groups could be made, and some preferential connections between sites and distance were identified. However, again this classification lacked to offer a solid typology with a meaningful quantitative representation (Agolli 2017: 319-326).

Another crucial aspect of the conceptual framework is its capacity to produce a clear background for potential groups that combinations of attributes could create among various sites. Given that the framework breaks down each attribute separately based on the degree of homogeneity, it does not offer a grasp on the degree to which two or three attributes among various groups are combined and if altogether they could yield potential groups. Here perhaps the implications of a purpose-oriented approach could contribute to understand better the quantitative significance of any possible groups that may be formed and their meaning to the regional and intra-regional networks.

However, it must be stressed that the conceptual approach did rectify three crucial aspects: first, it avoids the intuitive decisions that a scholar may take over the classification process. Each repertoire is categorized based on the steps conducted during the process of production. Second, it creates an objective overview regarding the qualitative and quantitative distribution of attributes. The progressive categorization of data into a key diagram offers a good understanding for the measurement of homogeneity and heterogeneity within a repertoire. The key diagram has the potential to measure the degree of variety as a tool to understand 'artisans' 


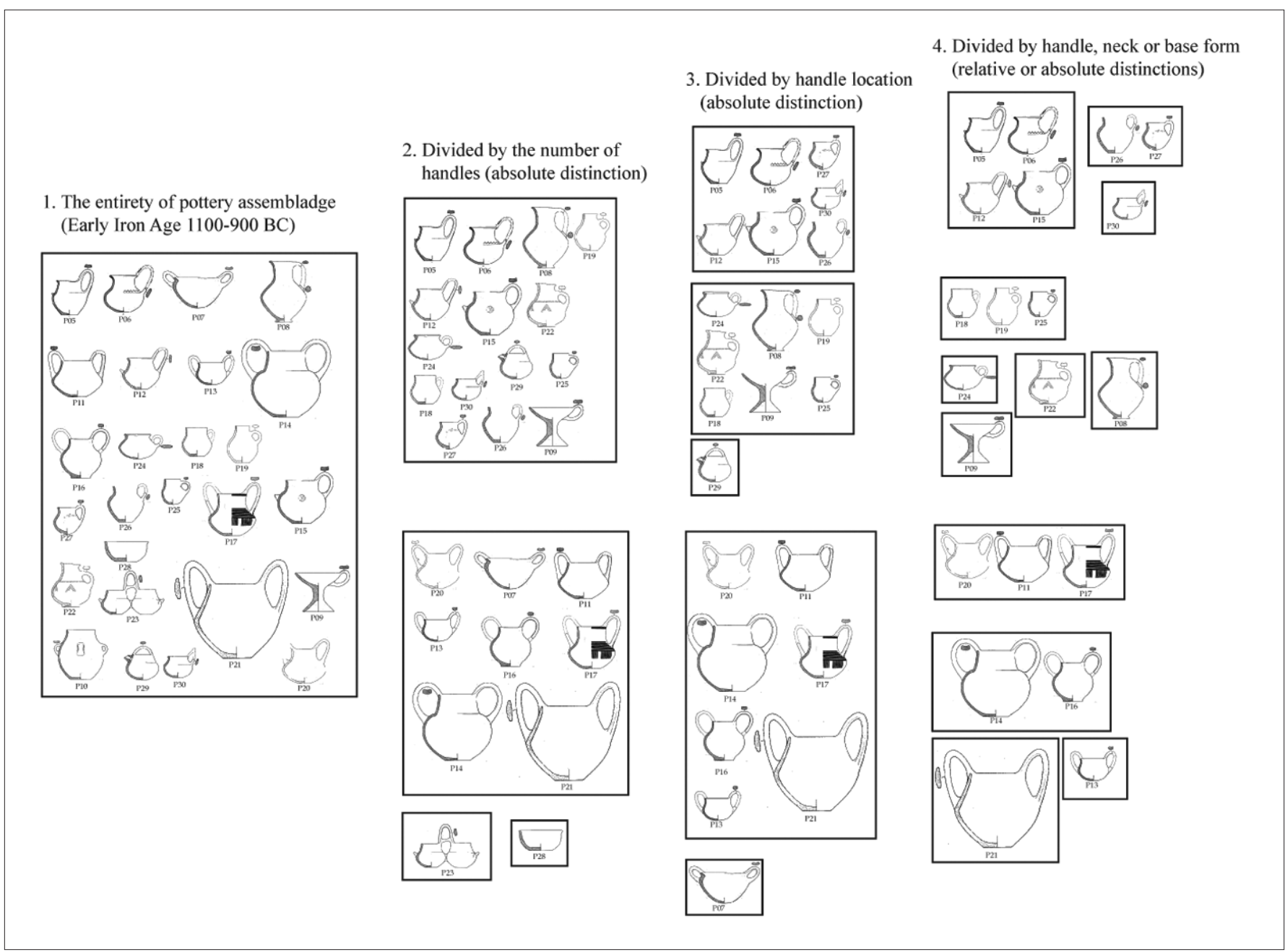

Figure 2. The formulation of the Key Diagram - the case of Prodan tumulus (Aliu 1984; Agolli 2014).

choices and how shared or individual concepts in one repertoire play a role in identifying networks outside a community. Third, it leaves open the possibility for further analysis, facilitating the sorting and distribution of various variables at regional and intra-regional scales. In each repertoire, the groups were quantitatively weak, however subsequent measurements that evaluate the weight of particular attributes could indicate potential patterns.

\section{Conclusions}

In this paper, I attempted to address a crucial issue which in Albanian studies of late prehistoric has a particular impact. Archaeometry and compositional analysis of the last decade have opened insightful avenues in pottery analysis making particular headway toward understanding the properties of data and the modes of production. However, with the case of the late prehistoric pottery in Albania, there are two crucial matters that make the application of a coherent classification framework rather fundamental. First and foremost, the current state of research and analysis does not offer a comprehensive account on the properties of the end-product. Over many decades, the excavations on tumuli burials and settlements have produced an immense number of vessels 
but have not quite evaluated the plethora of research questions that pottery could impose. The implications of a conceptual scheme of classification opens a venue towards new queries that involve understanding any dynamics that the quantitative and qualitative profile of a repertoire may represent, including site, regional, intraregional variability, measurement of innovation traits in the diachronic perspective, as well the degree of variability between shared and individual concepts as choices that are implied during the process of production. Second, above all, the application of the conceptual classification in the theoretical and methodological framework gives equal attention to any attribute. It avoids intuitive decisions and intends to offer a potential avenue to analyses and questions that pottery could prominently succeed to answer.

The paper addressed a crucially important aspect not only for the issue of classification per se but at a larger perspective to involve in the studies of material culture theoretical and methodological discourse, two parameters without which archaeology could not understand at depth issues that imply cultural or social dynamics.

\section{Acknowledgement}

Am very grateful to my friend and colleague Brett Kaufman for all the suggestions and recommendations he generously offered to the paper. 


\section{References}

Adams, W. Y. and Adams, E. W. 1991. Archaeological typology and practical reality: A dialectical Approach to Artifact Classification and Sorting, Cambridge University Press, Cambridge.

Agolli, E. 2009. The Evolution of Household Pottery Production in the Iron Age Pottery of the Kamenicë Tumulus in Southeast Albania: Toward New Principles, Theories and Methodologies in Pottery Studies, MA Thesis, Cotsen Institute of Archaeology, University of California Los Angeles.

Agolli, E. 2014.The Shaping of Social Complexity, Networks and Cultural Transmissions: Pottery from the Bronze and Iron Age Communities of Southern Illyria and Northern Epirus (2500-500 B.C.), PhD dissertation, Cotsen Institute of Archaeology, University of California, Los Angeles.

Agolli, E. 2017. Models of social networks of southeast Albania in the Late Bronze and Early Iron Age (1200-900 BC), In: M. Fotiadis, M., R. Laffineur, Y. Lolos and A. Vlachopoulos (eds), Proceedings of the $16^{\text {th }}$ International Aegean, Hesperos, The Aegean seen from the west, loanina, 319-326.

Agolli, E. 2019. The late prehistory in Albania: a review of theoretical agendas, strategies of research design and valorization of archaeological heritage. In: I. Miloglav, (ed), Proceedings ftom the $5^{\text {th }}$ Scientific conference, Methodology and Archaeology, Zagreb, 25-42.

Aliu, S. 1984. Tuma e Prodanit, lliria 14 (1), 27-67.

Aliu, S. 1994. Varreza e Borovës, lliria 24 (1-2), 5-57.

Aliu, S. 1995. Tuma e Psarit, lliria 25 (1-2), 119-48.

Aliu, S. 1996. Tuma e Shtikës, Iliria 26 (1-2), 57-78.

Aliu, S. 2002. Tuma e Luarasit, Akademia e Shkencave të Shqipërisë, Tiranë.

Aliu, S. 2012. Tuma e Rehovës, Akademia e Shkencave të Shqipërisë, Tiranë.

Aliu, S. and Bejko, L. 2009. Fibulat e varrezave të Kolonjës, Iliria 32 (1), 59-103.

Andrea, Zh. 1985. Kultura llire e Tumave në Pellgun e Korçës, Akademia e Shkencave të RPS të Shqipërisë, Tiranë.

Andrea, Zh. 2009. Tuma 1 e Shuecit (Rrethi i Korçës). Rezultatet e fushatës së parë të gërmimeve, Iliria 34, 223-79.

Bodinaku, N. 1989. Varreza tumulare e Pazhokut, Iliria 12 (1), 49-101.

Bodinaku, N. 1990. Rreth origjinës dhe bartësve të qeramikës së pikturuar mat të kohës së vonë të Bronzit dhe asaj të Hekurit, Iliria 21 (2), 65-96.

Bodinaku, N. 2001. Varreza tumulare e Dukatit në rrethin e Vlorës, Iliria 30 (1-2), 9-100.
Brown, J. A. 1971. The Dimensions of Status in the Burials at Spiro, Memoirs of the Society for American Archaeology 25, 91-112.

Colton, H. S. 1952. Pottery types of the Arizona strip and adjacent areas in Utah and Nevada, Northern Arizona Society of Science and Art, Flagstaff.

Colton, H. S. and Hargrave, L. L. 1937. Handbook of Northern Arizona pottery wares, Museum of Northern Arizona, Flagstaff, Bulletin 11.

Ford, A. J. 1954. On the concept of types, American Anthropologist 56 (1), 42-57.

Gifford, C. J. 1960. The Type-Variety method of ceramic classification as an indicator of cultural phenomena, American Antiquity 25, (3), 341-47.

Gori, M. 2015. Along the Rivers and Through the Mountains: A revised chrono-cultural framework for the southwestern Balkans during the late $3^{\text {rd }}$ and early $2^{\text {nd }}$ millennium $B C E$, Verlag Dr. Rudolf Habelt $\mathrm{GmbH}$, Bonn.

Hoti, A. 1981. Tumat e fshatit Kënetë (Gërmime të vitit 1977), lliria 11 (1), 211-217.

Jubani, B. 1969. Varreza tumulare e Çinamakut, Buletini Arkeologjik 1, 37-51.

Jubani, B. 1982. Tumat e Krumës (Rrethi i Kukësit), Iliria 12 (2), 147-95.

Jubani, B. 1983. Tumat ilire të Kënetës, lliria 13 (2), 77-134.

Korkuti, M. 1969. Qeramika e pikturuar e kohës së vonë të bronzit dhe e kohës së hershme të hekurit dhe karakteri llir i bartësve të saj, Studime Historike 3, 159-74.

Korkuti, M. 1971. Vendbanimi prehistorik i Trenit, lliria 1, 31-48.

Korkuti, M. 1981. Tuma e Patosit, Iliria 11 (1), 7-55.

Korkuti, M. and Bunguri, A. 1996. Kultura e epokës së bronzit në vendbanimin e Cetushit, lliria 26 (1-2), 5-19.

Krapf, T. 2014. The Late Bronze Age pottery of Macedonia: comparisons with the plain of Korçë, In: L. Stefani, N. Merousis, and A. Dimoula (eds), International Conference Proceedings, Archaeological Museum of Thessaloniki, Thessaloniki, 585-597.

Krieger, A. D. 1944. The Typological Concept, American Antiquity 9 (3), 271-88.

Morris, I. 1987. Burial and ancient society: The rise of the Greek city-state, Cambridge University Press, Cambridge.

Papadopoulos, J. K. 2005. The Early Iron Age Cemetery at Torone, Cotsen Institute of Archaeology, Los Angeles.

Pevnick, S. and Agolli, E. 2014. The pottery from the tombs 
and tumulus fill, In: J. K. Papadopoulos, S. P. Morris, L. Bejko and L. A. Schepartz (eds.) Excavations of the Prehistoric Burial Tumulus of Lofkënd in Albania, Monumenta Archaeologica 34, Cotsen Institute of Archaeology, Los Angeles, 227-324.

Prendi, F.1956. Mbi rezultatet e gërmimeve në fshatin Vodhinë të rrethit të Gjirokastrës, Buletin për Shkencat Shoqërore 1, 180-8.

Prendi, F. 1957. Tumat në fushën e fshatit Vajzë /Vlorë, Buletin për Shkencat Shoqërore 2, 76110.

Prendi, F. 1959. Tumat në fshatrat Kakavi dhe Bodrishtë të rrethit të Gjirokastrës, Buletin për Shkencat Shoqërore 4, 190-211.

Prendi, F. 1966. La civilisation préhistorique de Maliq, Studia Albanica 1, 255-80.
Prendi, F. 1977. Epoka e Bronzit në Shqipëri, Iliria 7-8, 5-58. Prendi, F. 1974. Vështrim mbi kulturën e periudhës së parë të epokës së hekurit në Shqipëri, Iliria 3, 103-30.

Read, D. 2007. Artifact Classification: A Conceptual and Methodological Approach, Walnut Creek California, Left Coast Press.

Rouse, I. 1960. The Classification of Artifacts in Archaeology, American Antiquity 25 (3), 31323.

Rouse, I. 1972. Introduction to Prehistory: A Systematic Approach, Mc Graw-Hill, New York.

Wheat, J. B., Gifford, J. C., and Wasley, W. 1958. Ceramic variety, type cluster and ceramic system in Southwestern pottery analysis, American Antiquity 24 (1), 37-47. 
